\title{
Actinobaculum schaalii an emerging pediatric pathogen?
}

\author{
Petra Zimmermann ${ }^{1}$, Livia Berlinger ${ }^{2,3}$, Benjamin Liniger ${ }^{4}$, Sebastian Grunt ${ }^{5}$, Philipp Agyeman ${ }^{1}$ \\ and Nicole Ritz ${ }^{1,6,7^{*}}$
}

\begin{abstract}
Background: Actinobaculum schaalii was first described as a causative agent for human infection in 1997. Since then it has mainly been reported causing urinary tract infections (UTI) in elderly individuals with underlying urological diseases. Isolation and identification is challenging and often needs molecular techniques. A. schaalii is increasingly reported as a cause of infection in humans, however data in children is very limited.

Case presentation: We present the case of an 8-month-old Caucasian boy suffering from myelomeningocele and neurogenic bladder who presented with a UTI. An ultrasound of the urinary tract was unremarkable. Urinalysis and microscopy showed an elevated leukocyte esterase test, pyuria and a high number of bacteria. Empiric treatment with oral co-trimoxazole was started.

Growth of small colonies of Gram-positive rods was observed after $48 \mathrm{~h}$. Sequencing of the 16S rRNA gene confirmed an A. schaalii infection 9 days later. Treatment was changed to oral amoxicillin for 14 days. On follow-up urinalysis was normal and urine cultures were negative.

Conclusions: A.schaalii is an emerging pathogen in adults and children. Colonization and subsequent infection seem to be influenced by the age of the patient. In young children with high suspicion of UTI who use diapers or in children who have known abnormalities of their urogenital tract, infection with A. schaalii should be considered and empiric antimicrobial therapy chosen accordingly.
\end{abstract}

Keywords: Actinobaculum schaalii, Children, Emerging infection, Urinary tract infection, Gram-positive, Antimicrobial susceptibility

\section{Background}

The genus Actinobaculum was first described as a cause of human infection in 1997 [1]. Since the initial description of the genus $A$. schaalii has been the most frequently reported human pathogen. It has mainly been reported causing urinary tract infection (UTI) in elderly people with underlying urological diseases. Like other Actinomyces-like organisms it is suspected to be part of the commensal flora of the human urogenital tract [1]. Since the introduction of molecular techniques into routine microbiological diagnosis, A. schaalii has increasingly been reported as a cause of infection in humans

\footnotetext{
* Correspondence: nicole.ritz@ukbb.ch

'Department of Paediatrics, University Children's Hospital, Berne, Switzerland ${ }^{6}$ Infectious Diseases Unit, University Children's Hospital Berne, Berne, Switzerland

Full list of author information is available at the end of the article
}

$[2,3]$. However data in children with $A$. schaalii infection is very limited [4].

\section{Case presentation}

An 8-month-old boy with a lumbosacral myelomeningocele surgically repaired shortly after birth and a hydrocephalus due to an Arnold-Chiari malformation was seen at our clinic for a routine appointment. He had not previously suffered from a UTI and did not need regular catheterization. On presentation he was afebrile and his physical examination was normal. A cystomanometry performed on the same day revealed an elevated bladder pressure and a residual urine volume of $25 \mathrm{ml}$, confirming the expected neurogenic bladder dysfunction. An ultrasound of the urinary tract was unremarkable. Urinalysis from a catheter specimen showed an elevated leukocyte esterase activity Microscopy of the urine showed more than 20 leukocytes, 5 to 10 erythrocytes, plus a high

\section{Ciomed Central}

(c) 2012 Zimmermann et al.; licensee BioMed Central Ltd. This is an Open Access article distributed under the terms of the Creative Commons Attribution License (http://creativecommons.org/licenses/by/2.0), which permits unrestricted use, distribution, and reproduction in any medium, provided the original work is properly cited. 
number of bacteria per high-power field. A UTI was postulated and the patient was empirically treated with oral co-trimoxazole (trimethoprim/sulfamethoxazole $5 / 25 \mathrm{mg} / \mathrm{kg}$ twice daily) for 7 days. According to standard procedure urine cultures were set up on a CHROMagar Orientation plate (Becton Dickinson AG, Basel, Switzerland) and a Columbia-Colistin-Nalidixic acid agar (CNA) plate (Becton Dickinson, Basel, Switzerland) with 5\% sheep blood. Growth of small colonies was observed on the CNA plate after $48 \mathrm{~h}$ of incubation at $35^{\circ} \mathrm{C}$ with $5 \%$ $\mathrm{CO}_{2}$, corresponding to $10^{4}$ colony forming units (CFU)/ $\mathrm{ml}$. The growing Gram-positive rods were catalasenegative and could not be identified by the API Coryne System (bioMérieux, Geneva, Switzerland). For further identification sequencing of the 16S rRNA gene by MicroSeq500 16S rDNA bacterial identification kit (Applied Biosystems, Darmstadt, Germany) was performed. Nine days later Basic Local Alignment Search Tool (BLAST) analysis of the resulting 477 base pair sequence was available and showed $100 \%$ identity with $A$. schaalii strain BD04-00146 (GenBank accession number AY957507.2).

Two weeks after the initial appointment the patient was reviewed. Microscopy of the urine continued to show 10 to 20 leukocytes and 10 to 20 erythrocytes per high-power field with presence of bacteria. Blood analysis showed a C-reactive protein of $9 \mathrm{mg} / \mathrm{l}$ and a leukocyte count of $7 \times 10^{9} / 1$. The combination of a repeatedly abnormal urinalysis and growth of $A$. schaalii in monoculture was considered diagnostic for a UTI. According to current recommendations for the treatment for A. schaalii infection oral amoxicillin $(15 \mathrm{mg} / \mathrm{kg}$ three times daily) was started $[3,5]$. The urine culture from the same day showed growth of coagulase-negative staphylococci. Eight days after starting amoxicillin, results of the urinalysis were normal and urine cultures were negative. The treatment with amoxicillin was continued for a total duration of 14 days.

\section{Discussion}

In children UTI is usually caused by gram-negative organisms, including Escherichia coli, Klebsiella spp., Pseudomonas spp. and Proteus spp.[6]. A. schaalii, a recently described pathogen, has to date mainly been associated with UTI in elderly individuals.

A total of 47 cases of $A$. schaalii infection have been published to date $[1,3,4,7-20]$. Of these, 41 cases (87\%) were reported in adults and only six cases in children under the age of 15 years (Table 1). All of those six children were symptomatic and treated with antibiotics. Two of the three children with cystitis and the child with pyelonephritis were febrile. In the case of the 15year old boy who presented with cystitis and the girl with an intradural abscess the temperature was not specified in the case report. Our case is, to our knowledge, the youngest child currently described with an A. schaalii UTI. It is also the first case where A. schaalii was treated in an asymptomatic child. In previous case reports from both children and adults a high proportion of individuals with an A. schaalii UTIs had an underlying urogenital pathology ( $83 \%$ and $85 \%$, respectively). All of the reported children were either using diapers or had enuresis. In two children a second pathogen was isolated: Klebsiella pneumoniae in a 3-year-old girl with recurrent UTI [21] and non-hemolytic streptococci in a 9-month-old girl with intradural abscess [10]. Further clinical details of all pediatric cases are summarized in the Table 1.

Our case highlights the clinical features and challenges in diagnosis and management of $A$. schaalii UTI. Isolation and identification of $A$. schaalii using standard laboratory techniques is difficult. Notably, A. schaalii requires $\mathrm{CO} 2$ enriched culture conditions and subsequent identification requires $16 \mathrm{~S}$ rRNA sequencing. Therefore the presence of Gram-positive rods in microscopy with a negative culture result should prompt the search for unusual pathogens including $A$. schaalii.

This may lead to a significant delay in identification resulting in prolonged or repeated antimicrobial therapy. Its resemblance to normal skin flora further impedes correct identification of the pathogen. In addition slow growing bacteria such as $A$. schaalii can get overgrown by faster-growing bacteria and therefore remain undetected. For this reason we opted to continue treatment in our patient until urinalysis had normalized. Implementation of the newer Matrix-assisted laser desorption/ ionization-Time Of Flight (MALDI-TOF) technology in routine diagnostic procedures may allow more rapid identification of $A$. schaalii in future, which might change the frequency of its detection.

A. schaalii has traditionally been thought to be part of the commensal flora of the human urogenital tract [1]. However, there is evidence that colonization with A. schaalii is dependent on risk factors including age, the presence of diapers and enuresis. For example, in asymptomatic patients above 60 years of age with negative results in a urine dipstick test, a real-time quantitative PCR assay detected A. schaalii in $22 \%$ of urine samples [2]. Similarly, in children suspected for UTI and negative results in urine dipstick test from midstream urine samples, PCR for A. schaalii from urine was positive in $36 \%$ ( 5 of 14) of children below three years of age but negative in all 15 children tested between 3 and 15 years of age [21].

Colonization seems to be a risk factor for infection with A. schaalii in children and adults as most case reports have been described in the same age group where colonization most frequently occurs. 
Table 1 Clinical details of reviewed pediatric cases with Actinobaculum schaalii infection

\begin{tabular}{|c|c|c|c|c|c|c|c|c|c|c|}
\hline $\begin{array}{l}\text { Age } \\
\text { (years) }\end{array}$ & Sex & $\begin{array}{l}\text { Clinical } \\
\text { presentation }\end{array}$ & Specimen with $A$. schaalii & Concomitant flora & $\begin{array}{l}\text { Underlying } \\
\text { urogenital tract } \\
\text { pathologies }\end{array}$ & $\begin{array}{l}\text { Other underlying } \\
\text { risk factors }\end{array}$ & Antibiotic treatment & $\begin{array}{l}\text { Duration of } \\
\text { treatment } \\
\text { (days) }\end{array}$ & Outcome & Reference \\
\hline 0.66 & m & cystitis & urine & none & neurogenic bladder & $\begin{array}{l}\text { myelomeningocele } \\
\text { diaper }\end{array}$ & $\begin{array}{l}\text { co-trimoxazole } \\
\text { followed by amoxicillin }\end{array}$ & $\begin{array}{l}7 \\
14\end{array}$ & recovery & our case \\
\hline 0.75 & $f$ & $\begin{array}{l}\text { cauda equina } \\
\text { syndrome }\end{array}$ & $\begin{array}{l}\text { pus from } \\
\text { intradural } \\
\text { abscess }\end{array}$ & $\begin{array}{l}\text { non-hemolytic } \\
\text { streptococci }\end{array}$ & none & $\begin{array}{l}\text { syringomyelia } \\
\text { diaper }\end{array}$ & penicillin, metronidazol & not specified & recovery & 10 \\
\hline 3 & f & cystitis & urine & $\begin{array}{l}\text { Klebsiella } \\
\text { pneumoniae }\end{array}$ & none & $\begin{array}{l}\text { recurrent UTI } \\
\text { diaper }\end{array}$ & $\begin{array}{l}\text { trimethoprim } \\
\text { followed by amoxicillin }\end{array}$ & $\begin{array}{l}7 \\
10\end{array}$ & recovery & 21 \\
\hline 5 & m & pyelonephritis & urine & none & $\begin{array}{l}\text { pyeloureteral junction } \\
\text { obstruction }\end{array}$ & $\begin{array}{l}\text { inborn right } \\
\text { hemispheric tissue } \\
\text { lesions with left-sided } \\
\text { hemiplegia epilepsy }\end{array}$ & $\begin{array}{l}\text { amoxicillin/clavulanic acid } \\
\text { followed by vancomycin }\end{array}$ & $\begin{array}{l}2 \\
14\end{array}$ & recovery & 4 \\
\hline 13 & m & cystitis & urine & none & neurogenic bladder & enuresis & $\begin{array}{l}\text { pivampicillin } \\
\text { followed by mecillinam } \\
\text { followed by pivampicillin }\end{array}$ & $\begin{array}{l}20 \\
10 \\
14\end{array}$ & $\begin{array}{l}\text { re-infection } \\
\text { after } 1 \text { year } \\
\text { recovery }\end{array}$ & 21 \\
\hline 15 & m & cystitis & urine & none & $\begin{array}{l}\text { neurogenic bladder } \\
\text { vesicoureteral reflux } \\
\text { bladder diverticulum }\end{array}$ & $\begin{array}{l}\text { myelomeningocele } \\
\text { paraplegia }\end{array}$ & amoxicillin/clavulanic acid & 7 & recovery & * \\
\hline
\end{tabular}


In our patient urine culture grew $10^{4} \mathrm{CFU} / \mathrm{ml}$ A. schaalii and in contrast to previous reports in children with $A$. schaalii UTI there were no clinical symptoms $[4,10,21]$. Similar colony counts have been found in children considered to be colonized with A. schaalii, however, none of these children had concomitant positive leukocyte esterase tests or pyuria [21]. In our patient the combination of a repeatedly pathologic urinalysis including a positive leukocyte esterase test and pyuria together with growth of $10^{4} \mathrm{CFU} / \mathrm{ml}$ of a recognized uropathogen in monoculture was considered sufficient evidence for the diagnosis of a cystitis. The vast majority of $A$. schaalii isolates are resistant to co-trimoxazole and ciprofloxacin, which are frequently used as empiric treatment in UTI in children and adults respectively. Current recommendations for the choice of antibiotic treatment for A. schaalii infection are amoxicillin or cephalosporins [5]. There is limited data from in vitro susceptibility testing suggesting that gentamicin, vancomycin, linezolid, nitrofurantoin and mecillinam are potential alternative treatment options [5,22]. The optimal duration of antibiotic treatment for $A$. schaalii infection is currently unknown. Most case reports suggest treatment duration of 7 to 14 days. Therefore we repeated the urine culture after eight days of antibiotic treatment, and stopped treatment after 14 days when negative culture results were available.

\section{Conclusions}

A. schaalii is an emerging pathogen in both children and adults. Colonization and subsequent infection seem to be influenced by a number of factors in particular age of the patient. In young children with high suspicion of UTI who use diapers or children who have known abnormalities of their urogenital tract, infection with A. schaalii should be considered and empiric antimicrobial therapy chosen accordingly. Further studies are needed to evaluate additional risk factors and to define optimal choice and duration of antibiotic treatment.

\section{Consent}

Written informed consent was obtained from the patient's parents for publication of this case report. A copy of the written consent is available for review by the Series Editor of this journal.

\section{Competing interests}

The authors declare that they have no competing interests.

\section{Authors' contributions}

PZ wrote the draft of the manuscript and preformed the literature review. BL and SG have been involved in patient's clinical care. LB preformed the microbiological and molecular diagnoses and wrote of the relevant section in the case report. PA and NR reviewed the manuscript. All authors read and approved the final manuscript.
Authors' information

Philipp Agyeman and Nicole Ritz joint authorship.

\section{Acknowledgements}

The authors thank Reto Lienhard, Department of Microbiology, La Chaux-deFonds for providing additional clinical data.

\section{Author details}

'Department of Paediatrics, University Children's Hospital, Berne, Switzerland. ${ }^{2}$ Institute for Infectious Diseases, University of Berne, Berne, Switzerland. ${ }^{3}$ Bioanalytica AG, Lucerne, Switzerland. ${ }^{4}$ Department of Paediatric Surgery, University Children's Hospital, Berne, Switzerland. ${ }^{5}$ Department of Neuropediatrics, Development and Rehabilitation, University Children's Hospital, Berne, Switzerland. 'Infectious Diseases Unit, University Children's Hospital Berne, Berne, Switzerland. IInfectious Diseases Unit, University Children's Hospital Basel, Spitalstrasse 33, Basel CH-4031, Switzerland.

Received: 28 April 2012 Accepted: 15 August 2012

Published: 28 August 2012

\section{References}

1. Lawson PA, Falsen E, Akervall E, Vandamme P, Collings MD: Characterization of some Actinomyces-like isolates from human clinical specimens: reclassification of Actinomyces suis (Soltys and Spratling) as Actinobaculum suis comb. nov. And description of Actinobaculum schaalii sp. nov. Int J Syst Bacteriol 1997, 47:899-903.

2. Bank S, Jensen A, Hansen TM, Søby KM, Prag J: Actinobaculum schaalii, a common uropathogen in elderly patients. Emerg Infect Dis 2010, 16:76-80.

3. Nielsen H, Søby KM, Christensen JJ, Christensen JJ, Prag J: ctinobaculum schaalii: a common cause of urinary tract infection in the elderly population. Bacteriological and clinical characteristiscs. Scan J Infect Dis 2010, 42:43-47.

4. Pajkrt D, Simmons-Smit AM, Savelkoul PH, van den Hoek J, Hack WW, van Furth AM: Pyelonephritis cuased by Actinobaculum schaalii in a child with pyeloureteral junction obstruction. Eur I Clin Microbiol Infect Dis 2003, 53:679-682.

5. Cattoir V, Varaca A, Greub G, Prod'hom G, Legrand P, Lienhard R: In vitro susceptibility of Actinobaculum schaalii to 12 antimicrobial agents and molecular analysis of fluoroquinolone resistance. J Antimicrob Chemother 2010, 65(12):2514-2517.

6. Larcombe J: Urinary tract infection in children. BMJ 1999, 319:1173-1175.

7. Sturm PD, Van Eijk J, Veltman S, Muleman E, Schüllin T: Urosepsis with Actinobaculum schaalii and Aerococcus urinae. J Clin Microbiol 2006, 44:625-654.

8. Gomez E, Gustafson DR, Rosenblatt JE, Patel R: Actinobaculcum Bacteremia: a Report of 12 Cases. J Clin Microbiol 2011, 49(12):4311-4313.

9. Fendukly F, Osterman B: Isolation of Actinobaculum schaalii and Actinobaculum urinale from a patient with chronic renal failure. J Clin Microbiol 2005, 43:3567-3569

10. Reinhard M, Prag J, Kemp M, Andresen K, Klemmensen B, Højlyng N, Sørensen SH, Christensen JJ: Ten cases of Actinobaculum schaalii infection: clinical relevance, bacterial identification, and antibiotic susceptibility. J Clin Microbiol 2005, 43:5305-5308.

11. Martinaud C, Gaillard T, Maslin J, Rivière P, Fournier R, Trueba F, Brisou P: Actinobaculum schaali bacteria in an aged male patient. Med Mal Infect 2008, 38:617-619.

12. Agudo S, Domingo D, Navarro JL, Arenal N, López-Brea M: Actinobaculum schaalii: A new cause of mastitis. Clin Microbiol Infect 2009, 15(S653):S4.

13. Hoenigl M, Leitner E, Valentin T, Zarfel G, Salzer HJ, Krause R, Grisold AJ: Endocarditis caused by Actinobaculum schaalii. Emerg Infect Dis 2010, 16:1171-1173.

14. Vanden Bempt I, Van Trappen S, Cleenwerck I, De Vos P, Camps K, Celens A, Van de Vyvere M: Actinobaculum schaalii causing Fournier's Gangrene. J Clin Microbiol 2011, 49(6):2369-2371.

15. Larios OE, Bernard KA, Manickam K, Ng B, Alfa M, Ronald A: First report of Actinobaculum schaalii urinary tract infection in North America. Diagn Microbiol Infect Dis 2010, 76:282-285.

16. Thomsen TR, Aasholm MS, Rudkjøbing VB, Saunders AM, Bjarnsholt T, Givskov M, Kirketerp-Møller K, Nielsen PH: The bacteriology of chronic venous leg ulcer examined by culture-independent molecular methods. Wound Rep Reg 2010, 18:38-49. 
17. García-Bravo M, González-Fernández MB, García-Castro MA, Jaime-Muniesa ML: Urinary tract infection caused by Actinobaculum schaalii in an elderly patient. Rev Esp Quimioter 2011, 24(1):52-53.

18. Ulger-Toprak N, Liu C, Summanen PH, Finegold SM: Murdochiella asaccharolytica gen. nov., sp. nov., a Gram-stain-positive, anaerobic coccus isolated from human wound specimens. Int I Syst Evol Microbiol 2010, 60:1013-1016.

19. Hesstvedt L, Hasseltvedt V, Aandahl E, Caugant D, Høiby EA: Septicaemia due to Actinobaculum schaalii. Scand J Infect Dis 2006, 38(8):735-737.

20. Haller P, Bruderer T, Schaeren S, Laifer G, Frei R, Battegay M, Flückiger U, Bassetti S: Vertebral osteomyelitis caused by Actinobaculum schaalii: a difficult-to-diagnose and potentially invasive uropathogen. Eur J Clin Microbiol Infect Dis 2007, 26:667-670.

21. Andersen LB, Bank S, Hertz B, Søby KM, Prag J: Actinobaculum schaalii, a cause of urinary tract infections in children? Acta Paediatr 2011, 101(5): e232-e234.

22. Andersen PK, Søby KM, Bank S, Prag J: In vitro susceptibility of Actinobaculum schaalii to mecillinam. J Antimicrob Chemother 2011, 66(9):2181-2182.

doi:10.1186/1471-2334-12-201

Cite this article as: Zimmermann et al: Actinobaculum schaalii an emerging pediatric pathogen? BMC Infectious Diseases 2012 12:201.

\section{Submit your next manuscript to BioMed Central and take full advantage of:}

- Convenient online submission

- Thorough peer review

- No space constraints or color figure charges

- Immediate publication on acceptance

- Inclusion in PubMed, CAS, Scopus and Google Scholar

- Research which is freely available for redistribution 